there was not a single bleeding episode in the 73 patients studied, and this may reflect the popular concept at the moment of varying degrees of disseminated intravascular coagulation in these patients (Sultan et al., 1973). This could also explain why 11 patients, not transfused, had higher platelet counts on completion of separation than before the procedure in spite of the inevitable small loss of platelets into the buffy layer. The other problem was a possible reduction in the remission rate of patients leucopheresed because of the necessary delay in getting them to our unit and setting up the separator (in practice this often caused a delay of up to 24 hours), a factor known to influence the treatment of myelogenous leukaemia (Crowther et al., 1970). It was reassuring to find that the remission rate in this disease was not altered. The $68 \%$ remission rate for the adult high-count lymphoblastic patients was the same as reported in other series (Medical Research Council, 1971).

Recently a Blood Cell Seperator (Haemonetics 5830 Model 30 Blood Processor, Natick, Mass., U.S.A.) has been designed which uses an intermittent bleeding cycle for centrifugation of the blood. This machine is much cheaper than the continuous flow blood cell seperators but has the disadvantages of altering the donor's blood volume and removing platelets. These problems can to some extent be overcome and we are at present evaluating this instrument for use with leukaemia patients.

The current results of immunotherapy in acute myelogenous leukaemia make it reasonable to suppose that immunological treatment of acute leukaemia may play a definite role in the future management of these patients, and by necessity this will involve patients distributed throughout the country (already the Medical Research Council Leukaemia Working Party have a pilot study involving four centres).

For this to become a practical reality, however, large stores of cells must be collected for subsequent distribution, and because acute myelogenous leukaemia is not common it is economically sensible that this only be done in a limited number of specialized centres that have the necessary equipment. Though this requires that new patients should, if at all possible, be sent to these centres before they start treatment it does not mean that they need remain under the care of these centres. Subsequently the stored cells can be sent back to the referring hospital so that immunotherapy can be given close to where the patient lives. Clearly, when leucopheresing patients it is critical to avoid undue delay in specific chemotherapy, so careful co-operation and organization are required.

We are indebted for the support for this study to the Leukaemia Research Fund, the Imperial Cancer Research Fund, the Joseph Frazer Strong Trust, and the Medical Research Council. We thank the nursing staff of the cell separator units at the Royal Marsden Hospital, Surrey, and St. Bartholomew's Hospital, London, for their care of the patients.

\section{References}

Bloom, H. I G., et al. (1973). British fournal of Cancer, 27, 253.

Buckner, D., et al. (1969). Blood, 33, 353.

Children's Cancer Study Group A, U.S.A. (1973). Vaccination for the Maintenance of Remission in Childhood Leukaemia. Personal communication.

Crowther, D., et al. (1970). British Medical fournal, 4, 513.

Currie, G. A. (1972). British Fournal of Cancer, 26, 141 .

Freireich, E. J., Judson, G., and Levin, R. H. (1965). Cancer Research, 25, 1516.

Graw, R. G., et al. (1969). Lancet, 2, 77.

Haddow, A., and Alexander, P. (1964). Lancet, 1, 452.

Halpern, N. N., et al. (1965). Comptes Rendues Societe de Biologique, 153, 919.

Mathe, G. (1969). British Medical Fournal, 4, 7.

Mathe, G. (1969). British Medical fournal, 4, 7. (1969). British fournal of Cancer, 23, 814.

Mathe, G., Amiel, J-L., and Schwarzenberg, L. (1971). In Bone Marrow Transplantation and Leucocyte Transfusions. Springfield, Illinois, Charles C. Thomas.

Medical Research Council (1971). British Medical fournal, 4, 189.

Parr, I. (1972). British fournal of Cancer, 26, 174.

Powles, R. L., et al. (1971 a). British Medical fournal, 1, 486.

Powles, R. L., et al. (1971 b). British Medical fournal, 3, 664.

Powles, R. L. (1973). British fournal of Cancer, 28, Supp. 1, p. 262

Powles, R. L., et al. (1973 a). British fournal of Cancer, 28, 365.

Powles, R. L., et al. (1973 b). Cryobiology, 10, 282.

Sultan, C., Heilmann-Gouault, M., and Tulliez, M. (1973). British fournal of Haematology, 24, 255.

\title{
“Locked-in" Syndrome: Report of Seven Cases
}

\author{
C. H. HAWKES
}

British Medical fournal, 1974, 4, 379-382

\section{Summary}

Seven cases of the "locked-in" syndrome are described. This is a disorder in which a conscious, mute patient is completely paralysed apart from some form of eye movement, usually as a result of an infarct in the ventral pons. Such patients are often assumed to be in coma and as a result may be distressed by inappropriate conversation around the bedside.

\footnotetext{
Wessex Neurological Centre, Southampton University Hospitals, Southampton SO9 4XY

C. H. HAWKES, M.D., M.R.C.P., Senior Neurological Registrar
}

\section{Introduction}

For over 30 years neurologists have been acquainted with akinetic mutism. This is a somewhat ill-defined syndrome in which the patient is unable to perform any action apart from eye movement, but appears awake though he is probably not conscious (Plum and Posner, 1966). The disorder has been associated with lesions in the basal ganglia, cingulate gyrus, and brain stem. There is another condition similar to akinetic mutism but having important differences which is known variously as the "locked-in" syndrome, pseudocoma, deefferented state, and cerebromedullospinal disconnexion. Patients with this condition are completely paralysed except for some eyeball or eyelid movement but retain consciousness and may communicate with the examiner by eye signalling. Unless the observer is familiar with the disorder there is a high probability that it will be missed and the patient pronounced unconscious.

Over the past five years seven cases of the locked-in syndrome have been seen at the Wessex Neurological Centre, which suggests that it may be more common than has been realized. 


\section{Present Series}

Details of the seven cases are summarized in the table. Case 7 is described below.

A 35-year-old normotensive housewife was well until February 1973, when she developed pain in the neck followed immediately by vertigo, diplopia, left hemiparesis, and slurred speech. Twentyfour hours later she was unable to move any limb or indeed any muscle except for those of the eye and eyelid. Next morning arch aortography showed a tapering occlusion of the right vertebral artery $1 \mathrm{~cm}$ distal to its origin and hypoplasia of the left vertebral artery. The presumptive diagnosis was a locked-in state due to pontine infarction.

Her eyes moved up or down on command but chiefly down. The left eye could be completely shut but the right only partially so and there were no lower facial movements at all. The pupils were slightly constricted, more so on the right, but their light and accommodation reactions were preserved. The jaw was tightly clenched and could not be moved voluntarily and there was total paralysis of the tongue, palate, pharynx, and neck. Likewise there was no voluntary limb movement present but painful stimulation brought about a decerebrate posture. Hearing was grossly intact. There was flaccidity of the right arm and leg whereas the left limbs were mildly spastic. All the tendon jerks were present (brisker on the left) and both plantar responses were extensor. Sensation to touch was impaired on the left but intact on the right.

Both the ciliospinal and "doll's-head" reflexes were absent. Ioecold irrigation of the ears, however, induced tonic lateral deviation of the eyes towards the cooled side. Thereafter her condition remained unchanged until six weeks later, when she developed a respiratory infection from which she died.

Apart from the bronchopneumonia and an old caseous tuberculous lymph node in the chest necropsy showed nothing abnormal outside the central nervous system. The basilar artery was normal but the left vertebral artery was less than $1 \mathrm{~mm}$ in diameter. The right vertebral was completely occluded by thrombus extending almost to the vertebrobasilar junction. There was softening in the pons and right cerebellar hemisphere whereas the cerebral hemispheres were intact.

Microscopical examination of the vertebral artery showed that it was occluded by organized thrombus. The internal elastic lamina was virtually intact but much of the media was destroyed and had been replaced by granulation tissue. There was no sign of arteritis in any vessel.

Sections through the brain stem showed a large area of infarction affecting the ventral pons with slight dorsal extension (fig. 1). The cerebellar lesion consisted of a zone of cystic malacia
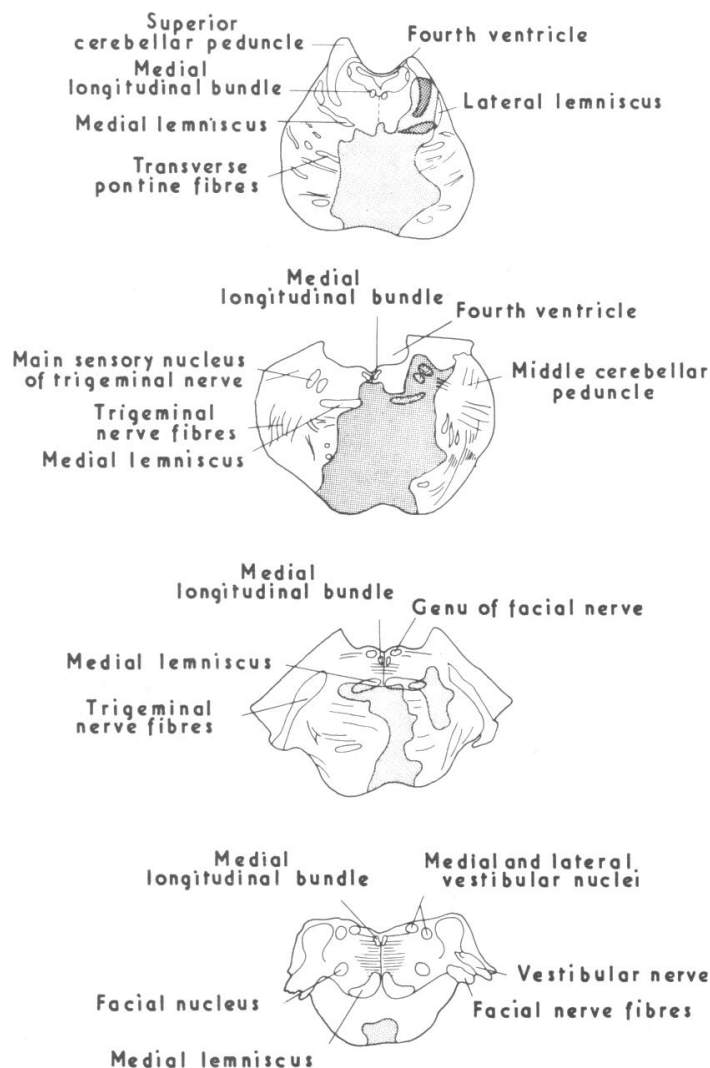

FIG. 1-Case 7. Transverse sections of brain stem showing area of infarction (shaded). In this and figs. 2 to 5 shaded areas represent only areas of complete destruction. All these areas were surrounded by zone of oedema, where function was likely to be severely disturbed.

involving the superior aspect of the right hemisphere. Microscopical examination of the cerebral cortex showed no abnormality.

The remaining six subjects were similar in that they had complete quadriplegia, decerebrate posturing on painful stimulation, normal pupillary light reflex, and preservation of some form of cutaneous sensation. Rudimentary com-

Details of Patients with Locked-in Syndrome

\begin{tabular}{|c|c|c|c|c|c|c|c|c|c|c|}
\hline $\begin{array}{c}\text { Case } \\
\text { No. }\end{array}$ & $\begin{array}{c}\text { Age } \\
\text { (Years) }\end{array}$ & Sex & $\begin{array}{l}\text { Provocative } \\
\text { Factors }\end{array}$ & $\begin{array}{l}\text { Voluntary } \\
\text { Movements }\end{array}$ & $\begin{array}{l}\text { Other } \\
\text { Features }\end{array}$ & $\begin{array}{c}\text { Lateral } \\
\text { "Doll's-head" } \\
\text { Reflex }\end{array}$ & $\begin{array}{c}\text { Ice Water } \\
\text { Caloric Test } \\
\text { Response }\end{array}$ & Survival & $\begin{array}{l}\text { Degree of } \\
\text { Recovery }\end{array}$ & Investigations \\
\hline 1 & 37 & M. & Asthmatic attack & Downward gaze & $\begin{array}{l}\text { Transient ocular } \\
\text { Bobbing. } \\
\text { Hyperventila- } \\
\text { tion. Ptosis }\end{array}$ & Absent & $\begin{array}{l}\text { Tonic abduction } \\
\text { of ipsilateral } \\
\text { eye towards } \\
\text { irrigated ear }\end{array}$ & $\begin{array}{l}\text { Died } \\
\quad 3 \text { months } \\
\text { later }\end{array}$ & $\begin{array}{l}\text { Lateral head } \\
\text { movement. } \\
\text { Opened and } \\
\text { closed eyes }\end{array}$ & $\begin{array}{l}\text { Necropsy, ventral } \\
\text { pontine embolism } \\
\text { See fig. } 2\end{array}$ \\
\hline 2 & 52 & F. & $\begin{array}{l}\text { Hyperchol- } \\
\text { esterolaemia } \\
\text { (type II). } \\
\text { Pneumogram }\end{array}$ & $\begin{array}{l}\text { Up and } \\
\text { downward } \\
\text { gaze. } \\
\text { Convergence }\end{array}$ & $\begin{array}{l}\text { Transient } \\
\text { ocular } \\
\text { bobbing. } \\
\text { Hyper- }\end{array}$ & Absent & Absent & $\begin{array}{l}\text { Died } \\
15 \text { months } \\
\text { later }\end{array}$ & $\begin{array}{c}\text { Lateral head } \\
\text { movement }\end{array}$ & $\begin{array}{l}\text { Necropsy, ventral } \\
\text { pontine } \\
\text { infarction } \\
\text { See fig. } 3\end{array}$ \\
\hline 3 & 31 & M. & $\begin{array}{l}\text { Hypertension. } \\
\text { ?Fat embolus } \\
\text { from fractured } \\
\text { femur }\end{array}$ & $\begin{array}{l}\text { Up and } \\
\text { downward } \\
\text { gaze }\end{array}$ & $\begin{array}{l}\text { Cheyne-Stokes } \\
\text { respiration }\end{array}$ & Not tested & Not tested & $\begin{array}{l}\text { Died } \\
\quad 1 \text { year } \\
\text { later }\end{array}$ & $\begin{array}{l}\text { Some movement } \\
\text { of right arm }\end{array}$ & $\begin{array}{l}\text { Necropsy, ventral } \\
\text { pontine } \\
\text { infarction }\end{array}$ \\
\hline 4 & 33 & F. & $\begin{array}{l}\text { ?Contraceptive } \\
\text { pill }\end{array}$ & $\begin{array}{l}\text { Eye opening } \\
\text { and closing. } \\
\text { Normal } \\
\text { eyeball } \\
\text { movements }\end{array}$ & & Not tested & Not tested & $\begin{array}{l}\text { Alive } \\
3 \frac{1}{2} \text { years } \\
\text { later }\end{array}$ & $\begin{array}{l}\text { Recovery of left } \\
\text { arm and leg. } \\
\text { Right side weak. } \\
\text { Slurred speech }\end{array}$ & $\begin{array}{l}\text { Lumbar puncture } \\
\text { result normal }\end{array}$ \\
\hline 5 & 37 & M. & Hypertension & $\begin{array}{l}\text { Opening and } \\
\text { closing eyes }\end{array}$ & & Absent & Absent & $\begin{array}{l}\text { Alive } \\
3 \text { years } \\
\text { later }\end{array}$ & $\begin{array}{l}\text { Right arm moves } \\
\text { weakly. Slurred } \\
\text { speech. Full eye } \\
\text { movements and } \\
\text { swallowing }\end{array}$ & $\begin{array}{l}\text { Left vertebral artery } \\
\text { occluded at level } \\
\text { of atlas. } \\
\text { Pneumogram }\end{array}$ \\
\hline 6 & 49 & M. & Hypertension & $\begin{array}{l}\text { Downward and } \\
\text { slight upward } \\
\text { gaze }\end{array}$ & $\begin{array}{l}\text { Cheyne-Stokes } \\
\text { breathing }\end{array}$ & Absent & $\begin{array}{l}\text { Nil on unilateral } \\
\text { irrigation. } \\
\text { Downward } \\
\text { gaze on } \\
\text { bilateral } \\
\text { irrigation }\end{array}$ & $\begin{array}{l}\text { Died on } \\
\text { 4th day }\end{array}$ & None & $\begin{array}{l}\text { Necropsy, ventral } \\
\text { pontine } \\
\text { infarction } \\
\text { See fig. } 5\end{array}$ \\
\hline 7 & 35 & F. & None & $\begin{array}{l}\text { Downward and } \\
\text { slight upward } \\
\text { gaze. Opening } \\
\text { and closing } \\
\text { eyes }\end{array}$ & $\begin{array}{l}\text { Impaired } \\
\text { sensation on } \\
\text { left }\end{array}$ & Absent & $\begin{array}{l}\text { Tonic abduction } \\
\text { of ipsilateral } \\
\text { eye towards } \\
\text { irrigated ear }\end{array}$ & $\begin{array}{l}\text { Died } \\
8 \text { weeks } \\
\text { later }\end{array}$ & None & $\begin{array}{l}\text { Necropsy, ventral } \\
\text { pontine } \\
\text { infarction } \\
\text { See fig. } 1\end{array}$ \\
\hline
\end{tabular}


munication was established in every subject by eye signals though there were periods when communication could not be established or if so only at a low level. In all but case 4 there were no voluntary lateral eye movements, nor could they be evoked reflexly by passive head turning (doll's-head reflex). Irrigation of the external auditory meati with ice water, however, produced a contraction of the ipsilateral lateral rectus in two of the five cases tested.

There was necropsy proof of severe ventral pontine infarction in cases $1,2,3$, and 6 (see figs. 2-5). In addition to major pontine damage case 1 showed numerous small embolic

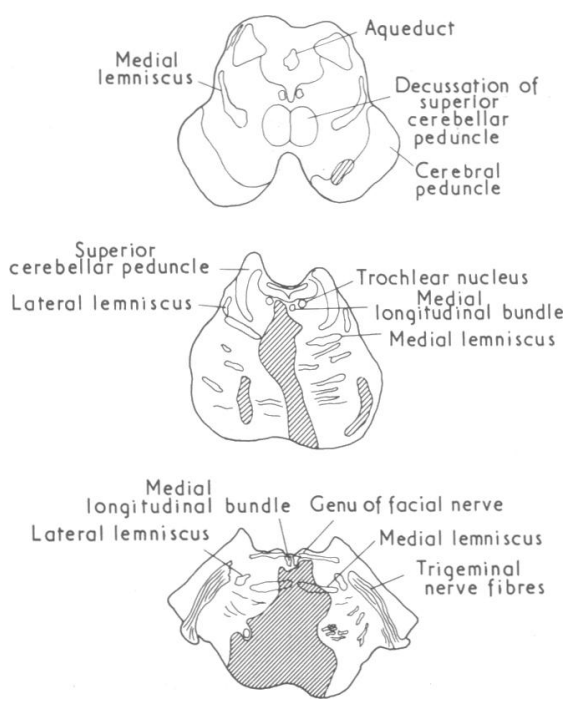

FIG. 2-Case 1. Transverse sections of brain stem showing area of infarction.

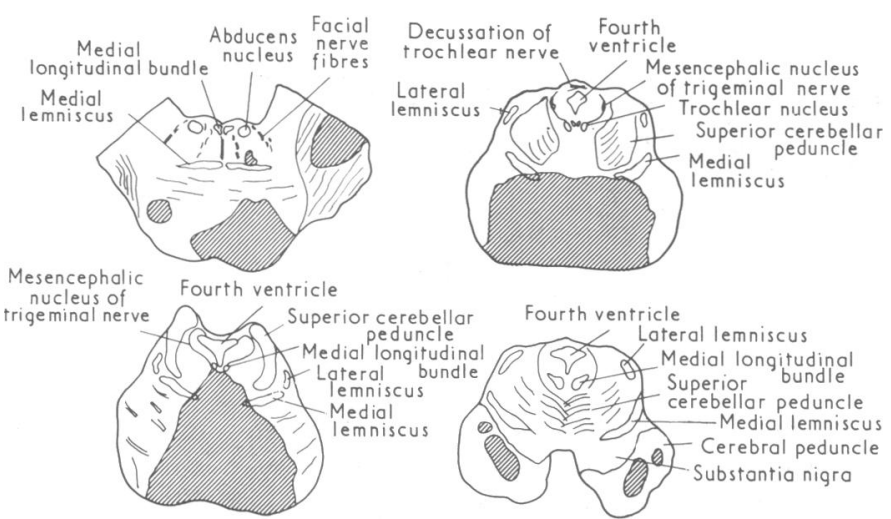

FIG. 3-Case 2. Transverse sections of brain stem showing area of infarction.

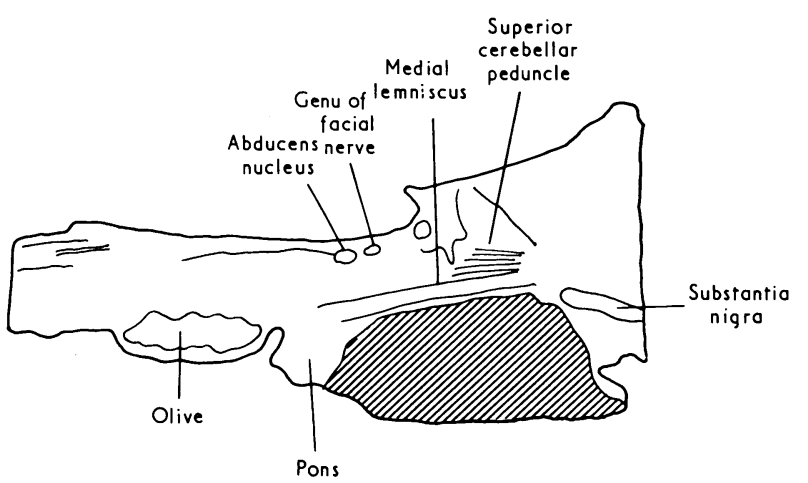

FIG. 4-Case 3. Longitudinal section of brain stem showing area of infarction.

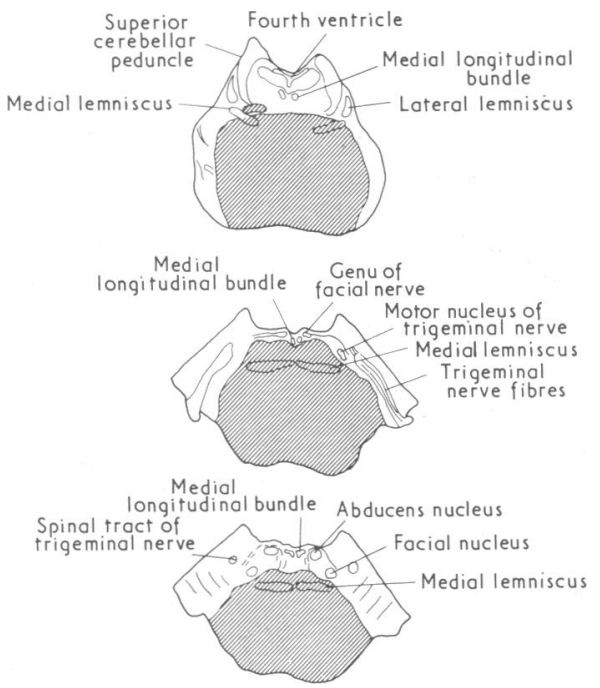

FIG. 5-Case 6. Transverse sections of brain stem showing area of infarction.

lesions scattered in the brain stem and cortex. Cases 4 and 5 can only be presumed to have had a pontine lesion. Both these patients abruptly developed a quadriplegia preceded by brain-stem symptoms (dysarthria, vertigo, and tinnitus), so that a pontine lesion was thought to be probable.

\section{Discussion}

The first report of a state resembling the locked-in syndrome was made by Darolles (1875) in a patient who had sustained basilar artery occlusion. Over the past 20 years there have been sporadic reports of the condition (Halsey and Downie, 1966; Chase et al., 1968) but attention was not focused on it until Nordgren et al. (1971) described seven such cases. Almost all patients so far described have susstained a ventral pontine infarction with variable extension dorsally and on occasion to adjacent areas of the mid-brain or medulla. A similar syndrome has been noted in a case of central pontine myelinolysis (Adams et al., 1959) and transiently in a subject with heroin overdosage (Hall and Karp, 1973). Plum and Posner (1966) mentioned that a de-efferented state could occur "to some degree" in myasthenia gravis, peripheral neuropathy, poliomyelitis, and vascular or demyelinating lesions of the medulla. Recently (Karp and Hurtig, 1974) the locked-in state has been reported in a patient with infarction of both cerebral peduncles secondary to basilar artery thrombosis. With the exception of the medullary lesion it is unlikely that such patients would be thought unconscious, whereas coma is readily simulated in the locked-in state due to pontine damage.

Traversing the ventral pons are the corticospinal and corticobulbar tracts, hence the voluntary motor supply to the limbs and medullary motor nuclei are disrupted. If the corticofacial fibres, which cross in the upper pons, escape the rostral limit of infarction facial movements may remain intact, but this is rarely found.

The medial lemniscus situated just dorsal to the pyramidal tracts was often involved in our cases yet cutaneous sensation was grossly intact (except for case 7), presumably because of preservation of the spinøthalamic pathway, which is more laterally placed. Abolition of lateral gaze probably resulted from damage to either the lateral gaze centre (adjacent to the abducens nucleus) or its connexions from the cortex. Ventical gaze, however, was preserved because the centre for this is located in or just rostral to the superior colliculi, and in no case was there evidence of more than minimal mid-brain involvement. By the same token the pupillary light reflexes 
were normal but some pupilloconstriction did occur, probably as a result of interruption of sympathetic fibres.

The doll's head and caloric tests, well described by Plum and Posner (1966), may help to locate the brain-stem lesion. Nordgren et al. (1971), like ourselves, usually found conjugate lateral eye movement to be absent both voluntarily and reflexly as judged by the doll's head and caloric tests. This probably results from destruction of the lateral gaze centres on both sides in addition to the ventral pontine damage. Two of our patients, however, displayed tonic abduction of the ipsilateral eye towards the ear irrigated with ice water. This indicates that the medial longitudinal bundle is bilaterally destroyed but that the abducens nucleus is intact. This point is well illustrated in fig. 1, where the area of complete destruction has spared the sixth nerve nucleus and falls just short of the medial longitudinal bundle but is almost certainly impairing its function.

At first sight it is surprising that patients who have such an extensive lesion are not unconscious. A possible explanation (Nordgren et al., 1971) is that so far as the brain stem is concerned consciousness depends on the integrity of the reticular formation in the rostral pons and midbrain, areas which are preserved in the locked-in syndrome. Indeed the E.E.G.s from all our subjects (Hawkes and Bryan-Smyth, 1974) were normal or nearly so, in keeping with their alert state.

The locked-in syndrome is often overlooked and the misdiagnosis of true coma made, probably because of a failure to test voluntary vertical conjugate gaze, which is often the only movement of which such patients are capable. Many were referred to our E.E.G. department as "unexplained coma" but almost all their records were those of wakefulness (Hawkes and Bryan-Smyth, 1974).

In contrast to the series of Nordgren et al. (1971) our patients were distinctly younger (mean age 39 years) and survived longer (mean survival 14 months) whereas their patients were mostly over 60 and died within one week. Despite our longer survival rate the two survivors can hardly be said to have made a worthwhile recovery. Both regained speech and some limb movement but remained confined to a wheelchair.

It has been suggested (Jennett and Plum, 1972) that the terms "locked in," "akinetic mutism," etc., be abandoned and grouped as "persistent vegetative state." Some patients with the latter condition, however, will be conscious and others not, a distinction obviously of clinical importance. Though the term "locked in" is perhaps not ideal it does help to draw attention to the plight of vegetative patients who are aware of their environment and need sympathetic handling.

I wish to thank Dr. G. S. Graveson and Dr. R. O. Weller for their advice in writing this article, and Mr. R. Hunt for technical help. I am also indebted to Dr. P. K. Robinson, Dr. L. S. Illis, Mr. J. Brice, and Mr. J. S. Garfield for permission to write up cases under their care.

\section{References}

Adams, R. D., Victor, M., and Mancall, E. L. (1959). Archives of Neurology and Psychiatry, 81, 154

Chase, T. N., Moretti, L., and Prensky, A. L. (1968). Neurology (Minneapolis), 18, 357.

Progrès Médical, 3, 629.

Hall, J. H., and Karp, H. R. (1973). Neurology (Minneapolis), 23, 6.

Halsey, J. H., and Downie, A. W. (1966). Fournal of Neurology, Neurosurgery and Psychiatry, 29, 350.

Hawkes, C. H., and Bryan-Smyth, L. (1974). Neurology (Minneapolis). In press.

Jennett, B., and Plum, F. (1972). Lancet, 1, 734

Karp, J. S., and Hurtig, H. I. (1974). Archives of Neurology, 30, 176

Nordgren, R. E., et al. (1971). Neurology (Minneapolis), 21, 1140.

Plum, F., and Posner, J. D. (1966). Diagnosis of Stupor and Coma. Philadelphia, Davis.

\title{
Role of Serial Plasma C.E.A. Assays in Detection of Recurrent and Metastatic Colorectal Carcinomas
}

\author{
A. M. MACKAY, S. PATEL, S. CARTER, U. STEVENS, D. J. R. LAURENCE, \\ E. H. COOPER, A. M. NEVILLE
}

British Medical fournal, 1974, 4, 382-385

\section{Summary}

Serial estimations of plasma carcinoembryonic antigen (C.E.A.) levels have been carried out in 220 patients with colorectal carcinomas who had potentially and apparently curative surgery. In a two-year follow-up period 53 patients developed recurrences or metastases. In 36 of these patients sustained rises in plasma C.E.A. titres

Institute of Cancer Research: Royal Cancer Hospital, Chester Beatty Research Institute, London SW3 6JB

A. M. MACKAY, M.D., M.R.C.PATH., Reader in Pathology

S. PATEL, Junior Technician

S. CARTER, Junior Technician

D. JR LAURENCE, PH.D., Senior Scientist

A. M. NEVILLE, M.D., M.R.C.PATH., Professor of Experimental Pathology

Department of Experimental Pathology and Cancer Research, School of Medicine, Leeds LS2 9NL

E. H. COOPER, M.D., F.R.C.P., Professor of Cancer Research occurred synchronously with or between three and 18 months before the clinical detection of recurrences or metastases. The use of serial plasma C.E.A. assays is therefore recommended as an additional diagnostic aid for the earlier detection of recurrent or metastatic colorectal carcinomas.

\section{Introduction}

Previous studies have shown that estimation of the plasma levels of carcinoembryonic antigen (C.E.A.) (Gold and Freedman, 1965) has limited value in the diagnosis or differential diagnosis of localized carcinomas of the colon and rectum (Moore et al., 1971; Holyoke et al., 1972; Laurence et al., 1972; Zamcheck et al., 1972; Mach et al., 1973; Elias et al., 1974; Skarin et al., 1974).

Raised plasma C.E.A. levels, however, occur more frequently once the colorectal carcinomas have spread outside the confines of the bowel and especially with spread to the liver. These values return to normal with apparently complete surgical resection of the tumour. 